\title{
Pengembangan Bahan Ajar Keterampilan Menulis Esai dan Cerita Pendek untuk Santri
}

\author{
Dyah Ayu Fitriana $^{1}$, Sulton ${ }^{1}$, Agus Wedi ${ }^{1}$ \\ ${ }^{1}$ Teknologi Pembelajaran-Universitas Negeri Malang
}

\section{INFO ARTIKEL}

\section{Riwayat Artikel:}

Diterima: 09-07-2019

Disetujui: 23-01-2020

\section{Kata kunci:}

teaching materials; essay writing skills;

short story;

bahan ajar;

keterampilan menulis esai;

cerita pendek

\author{
Alamat Korespondensi: \\ Dyah Ayu Fitriana \\ Teknologi Pembelajaran \\ Universitas Negeri Malang \\ Jalan Semarang 5 Malang \\ E-mail: fitriyes23@gmail.com
}

\begin{abstract}
ABSTRAK
Abstract: This research aims to develop writing skill essay and short story learning materials for santri with integrate project based learning models. Using ADDIE models, this research produce a learning materials with four part. Project based learning is integrated on the part called "Proyek Keren Kita" (Our Cool Project). This product verified to materials expert, learning media expert, and audience. Based on the verification and test obtained percentage of eligibility aspect is $93,75 \%$, feasibility aspects $100 \%$, graphics aspects $99,3 \%$, language aspects $100 \%$, interestness of teaching materials $85,28 \%$, and ease of understanding aspects $86,82 \%$ that means the producs are feasible to be used and disseminated.

Abstrak: Penelitian ini bertujuan untuk menghasilkan produk bahan ajar keterampilan menulis esai dan cerita pendek untuk santri yang berbasis project based learning. Metode pengembangan yang digunakan dalam penelitian ini adalah metode ADDIE. Secara umum bahan ajar yang dihasilkan terdiri dari empat bagian. Metode project based learning diintegrasikan ke dalam bahan ajar secara langsung dalam aktivitas yang diberi nama "Proyek Keren Kita". Produk tersebut selanjutnya diujicobakan kepada ahli materi, ahli media dan pengguna/santri. Berdasarkan uji coba tersebut diperoleh persentase aspek kelayakan isi sebesar $93,75 \%$, aspek kelayakan penyajian $100 \%$, aspek kegrafikan $99,3 \%$, aspek kebahasaan $100 \%$, aspek kemenarikan bahan ajar $85,28 \%$ dan aspek kemudahan pemahaman bahan ajar $86,82 \%$ yang berarti bahan ajar ini layak untuk digunakan dan disebarluaskan.
\end{abstract}

Keterampilan menulis merupakan salah satu kemampuan yang penting untuk dikembangkan di kalangan santri (Aziz, 2011). Menulis merupakan proses menuangkan hasil pemikiran, pendapat sehingga dapat mengembangkan kemampuan dalam berpikir dinamis (Yarmi, 2014). Hal ini disebabkan menulis melibatkan proses bernalar, mencurahkan ide dalam tulisan dan merevisinya secara berulang (Abidin, dkk, 2018) yang merupakan salah satu keunggulan yang perlu dibiasakan pada santri. Sesuai dengan hal tersebut, tujuan pembelajaran menulis juga untuk menghasilkan berbagai genre tulisan sesuai dengan tujuan, konteks, dan sasaran pembacanya. Akan tetapi, tujuan tersebut masih terkendala oleh kurangnya sumber belajar yang dapat memicu santri untuk mengasah kemampuan kreatif produktif dalam menghasilkan berbagai genre tulisan yang bernilai lebih.

Untuk membantu santri mencapai kompetensi yang diharapkan, maka bahan ajar haruslah dikembangkan dengan berbasis pada strategi maupun model pembelajaran yang dipilih. Model bahan ajar tersebut dikembangkan sejalan dengan langkah-langkah model pembelajaran yang sudah dipilih (Ernalis, dkk, 2012). Dalam penelitian pengembangan ini metode pembelajaran yang dipilih untuk diintegrasikan dalam bahan ajar adalah project based learning. Hal ini dikarenakan project based learning menekankan pada terciptanya sebuah produk atau karya sebagai hasil pembelajaran (Sutama, 2013).

\section{METODE}

Penelitian ini merupakan jenis penelitian Pengembangan (Developmental Research) yang bertujuan untuk mengembangkan suatu produk dan menguji kelayakan produk yang telah dikembangkan. Fokus penelitian yakni mengembangkan bahan ajar menulis esai dan cerita pendek berbasis proyek yang layak untuk digunakan dalam pembelajaran. Model yang digunakan dalam penelitian pengembangan ini terinspirasi dari model ADDIE (Reiser \& Mollenda, 1990-an dalam Tung, 2017). ADDIE terdiri dari lima langkah, yaitu Analysis (Analisis), Design (Perencanaan), Develop (Pengembangan), Implement (Penerapan), Evaluate (Evaluasi) (Sharifah \& Faaizah, 2015). 
Subjek dalam uji coba ini adalah validator dan santri. Dua orang ahli media pembelajaran dan ahli materi bahasa Indonesia dilibatkan dalam penelitian ini. Ahli media pembelajaran memvalidasi aspek kelayakan kegrafikan dan bahasa, sedangkan ahli materi memvalidasi kelayakan isi dan penyajian. Sementara itu, sebagai subjek uji coba lapangan adalah 15 santri Pondok Pesantren Darun Nun Malang. Jenis data yang akan diperoleh dari penelitian ini yaitu data kualitatif dan kuantitatif. Data kualitatif berupa tanggapan dan saran dianalisis kemudian ditarik kesimpulan secara deskriptif (Raco, 2013), sedangkan data kuantitatif berupa skor angket dianalisis dengan menggunakan rumus berikut. Hasil persentase kelayakan kemudian dianalisis sesuai dengan kriteria pada tabel 1.

$$
P=\frac{\sum x}{\sum x 1} \times 100 \%
$$

Keterangan:

$$
\begin{array}{ll}
\mathrm{P} & =\text { Persentase kelayakan } \\
\sum x & =\text { Jumlah skor total yang diperoleh dari angket } \\
\sum x 1 & =\text { Jumlah skor total skor ideal (maksimum) }
\end{array}
$$

Tabel 1. Kriteria Kelayakan Produk Pengembangan

\begin{tabular}{cl}
\hline Persentase (\%) & Kriteria Kelayakan \\
\hline $80-100$ & Sangat layak \\
$66-79$ & Layak \\
$56-65$ & Cukup layak \\
$40-55$ & Kurang layak \\
$30-39$ & Tidak layak \\
\hline
\end{tabular}

\section{HASIL}

Pemaparan hasil pada penelitian ini dibagi menjadi dua bagian, yakni proses pengembangan bahan ajar keterampilan menulis esai dan cerita pendek; Kelayakan produk bahan ajar keterampilan menulis esai dan cerita pendek. Uraian pemaparan hasil disajikan sebagaimana berikut.

\section{Proses Pengembangan Bahan Ajar Keterampilan Menulis Esai dan Cerita Pendek}

Prosess pengembangan bahan ajar ini mengikuti metode ADDIE atau Analysis, Design, Development, Implementation, Evaluation. Pertama, pada tahap analisis dilakukan beberapa proses awal yakni wawancara kepada pengasuh pondok pesantren, ustad yang mengajar kepenulisan, observasi terhadap santri Pondok Pesantren Darun Nun, juga mempelajari buku teks dan bahan ajar yang terkait dengan kepenulisan cerpen dan esai. Hasil wawancara dan observasi menunjukkan bahwa di Pondok Pesantren Darun Nun dibutuhkan bahan ajar keterampilan menulis yang berorientasi pada pengembangan kompetensi kreatif produktif terhadap penuangan gagasan atau ide baik ke dalam genre tulisan fiksi maupun non fiksi. Analisis juga menemukan bahwa kemampuan dan minat santri yang beragam menyebabkan dibutuhkannya bahan ajar yang memuat konten fiksi maupun non fiksi. Konten fiksi diwakili dengan cerita pendek sedangkan non fiksi diwakili dengan esai.

Kedua, proses mendesain bahan ajar. Pada tahap desain yang dilakukan pertama kali adalah menentukan outline bahan ajar dan tujuan pembelajaran di setiap bab. Outline awal bahan ajar ini terdiri dari empat bab (1) latar belakang dan manfaat menulis, (2) jenis-jenis tulisan, (3) belajar menulis esai, dan (4) belajar menulis cerpen. Setelah itu diuraikan tujuan pembelajaran bagi setiap bab. Bab pertama bertujuan untuk memberikan pengetahuan serta alasan terkait kebermanfaatan menulis dengan harapan dapat memberikan motivasi bagi santri yang belajar. Bab jenis-jenis tulisan bertujuan untuk memberikan pengetahuan dan pemahaman bagi santri ragam tulisan apa saja yang nanti dapat ditulisanya. Bab ketiga, belajar menulis esai. Pada bab ini santri sudah dikenalkan kepada salah satu genre tulisan nonfiksi yakni esai. Bab ini selain memaparkan perihal pemahaman tentang unsur tulisan esai, contoh juga akan memberikan pengalaman melalui pemberian proyek. Bab belajar menulis cerita pendek juga berisi pemahaman tentang unsur-unsur cerita pendek dilengkapi dengan pembelajaran proyek menulis cerpen. Kedua bab tersebut bertujuan untuk memberikan pemahaman serta pengalaman pada santri dalam menghasilkan tulisan.

Ketiga, pengembangan bahan ajar. Kegiatan yang dilakukan oleh peneliti pada bagian ini yakni mengembangkan materi sesuai dengan tujuan pembelajaran yang telah ditentukan. Penyusunan materi ke dalam bahan ajar ini diramu dari berbagai sumber bahan ajar dan buku teks yang relevan. Bahan ajar keterampilan menulis esai dan cerita pendek ini disusun menjadi buku setebal 72 halaman kertas B5. Pengembangan setiap bab terdiri dari (a) latar belakang menulis bagi santri, manfaat menulis bagi santri, keduanya ada pada bab pertama, (b) jenis tulisan yang meliputi pengalaman pribadi, biografi, cerita pendek, dongeng, puisi, esai, opini, resensi buku, yang ada pada bab kedua, (c) pengertian esai, manfaat menulis esai, ciri tulisan esai, unsur-unsur esai, contoh esai dan pembelajaran dengan proyek terkait esai berada pada bab ketiga, dan (d) pengertian cerita pendek, manfaat membaca dan menulis cerita pendek, unsur-unsur pembangun cerita pendek, contoh cerita pendek dan pembelajaran proyek cerita pendek ada pada bab keempat. 
Pengembangan metode pembelajaran project based learning atau pembelajaran berbasis proyek di bahan ajar ini ada pada dua tempat yakni bab belajar menulis esai dan bab belajar menulis cerita pendek. Hasil yang didapatkan yakni berjudul proyek keren kita yang meliputi kegiatan (a) aku perlu tahu, (b) rencana proyek kita dan timeline proyek, (c) mengumpulkan data, (d) mencipta kerangka, (e) menilai proyek, dan (f) mempublikasikan esai. Tahap terakhir dari pengembangan yakni melengkapi unsur-unsur buku yakni mendesain cover depan dan belakang, membuat daftar isi, kata pengantar, petunjuk penggunaan buku, latihan, daftar pustaka, memberi ilustrasi, serta mendesain bagian dalam buku bahan ajar ini.

\section{Kelayakan Produk Bahan Ajar Keterampilan Menulis Esai dan Cerita Pendek}

Data kelayakan produk bahan ajar keterampilan menulis esai dan cerita pendek diperoleh dari hasil angket yang diberikan kepada ahli materi, ahli media, serta uji coba yang meliputi uji coba perorangan, kelompok kecil dan lapangan yang dilakukan terhadap 21 santri. Hasil angket dari validator ahli materi dengan penilaian disajikan pada tabel 2.

Tabel 2. Hasil Uji Validitas Ahli Materi

\begin{tabular}{lllll}
\hline No. & Aspek & $\sum \mathbf{x}$ & $\sum \mathbf{x 1}$ & $\mathbf{\%}$ \\
\hline 1 & Kesesuaian materi & 12 & 12 & $100 \%$ \\
2 & Keakuratan materi & 8 & 8 & $100 \%$ \\
3 & Kemutakhiran & 8 & 8 & $100 \%$ \\
4 & Kemampuan mendorong keingintahuan & 7 & 8 & $75 \%$ \\
5 & Teknik penyajian & 8 & 8 & $100 \%$ \\
6 & Pendukung penyajian & 20 & 20 & $100 \%$ \\
7 & Penyajian pembelajaran & 8 & 8 & $100 \%$ \\
8 & Koherensi dan keruntutan alur pikir & 8 & 8 & $100 \%$ \\
\hline & TOTAL & 79 & 80 & $98,75 \%$ \\
\hline
\end{tabular}

Aspek kelayakan isi dan penyajian mendapatkan skor 79 dengan skor maksimum 80 poin. Berdasarkan pengolahan data ahli materi di atas, hasil perhitungan persentase tingkat kevalidan materi bahan ajar adalah $98.75 \%$. Berdasarkan angket yang diberikan kepada ahli materi, diperoleh saran untuk melakukan perbaikan pada kata-kata dan juga kalimat yang kurang tepat. Upaya yang pengembang lakukan adalah melakukan perbaikan pada kata-kata yang kurang tepat dan kalimat-kalimat yang kurang efektif. Hasil angket dari validator ahli media dengan penilaian disajikan pada tabel 3.

Tabel 3. Hasil Uji Validitas Ahli Media

\begin{tabular}{cllll}
\hline No. & Aspek & $\sum \mathbf{x}$ & $\sum \mathbf{x 1}$ & $\mathbf{\%}$ \\
\hline 1 & Ukuran bahan ajar & 4 & 4 & $100 \%$ \\
2 & Desain sampul bahan ajar & 20 & 20 & $100 \%$ \\
3 & Desain isi & 23.5 & 24 & $97.91 \%$ \\
4 & Kelayakan bahasa & 48 & 48 & $100 \%$ \\
\hline & TOTAL & 95.5 & 96 & $99.47 \%$ \\
\hline
\end{tabular}

Aspek kelayakan kegrafikan dan kelayakan bahasa mendapatkan skor 95,5 dengan skor maksimum 96 poin. Skor tersebut kemudian dihitung menggunakan rumus persentase validitas. Berdasarkan pengolahan data ahli media di atas, hasil perhitungan persentase tingkat kevalidan media bahan ajar adalah 99.47\%. Berdasarkan angket yang diberikan kepada ali media pembelajaran, diperoleh saran untuk melakukan perbaikan pada penggunaan warna teks dan background yang terlalu terang pada peta konsep. Upaya yang dilakukan oleh pengambang adalah mengganti warna background agar tulisan lebih terlihat kontras dan terbaca dengan baik. Pada tahap uji coba lapangan, subjek uji coba berjumlah 15 santri yang bermukim di pondok pesantren darun nun malang. Dari angket tanggapan yang telah disebarkan setelah uji coba lapangan diperoleh nilai sebagaimana ditunjukkan pada tabel 4 .

Tabel 4. Hasil Uji Coba Lapangan

\begin{tabular}{cllll}
\hline No. & Aspek & $\sum \mathbf{x}$ & $\sum \mathbf{x} \mathbf{1}$ & $\mathbf{\%}$ \\
\hline 1 & Kemenarikan buku & 307 & 360 & $85.28 \%$ \\
2 & Kejelasan/Kemudahan pemahaman buku & 573 & 660 & $86.82 \%$ \\
\hline & TOTAL & 932 & 1080 & $86.29 \%$ \\
\hline
\end{tabular}

Berdasarkan pengolahan data hasil penilaian uji coba lapangan ini persentase tingkat kepraktisan bahan ajar adalah 86,29\%. Selain itu, juga didapatkan saran terkait perbaikan pada bahan ajar dari pengguna yakni perlunya penambahan gambar, alternatif lain untuk penjelasan masalah proyek yang sebelumnya menggunakan augmented reality dan QR code, serta pemberian ruang untuk ISBN dan profil penulis di cover belakang. 


\section{PEMBAHASAN}

Pada pembahasan penelitian ini ada dua bagian, yakni kajian hasil pengembangan produk bahan ajar dan kajian terkait hasil uji kelayakan produk bahan ajar yang dikembangkan.

\section{Kajian Hasil Pengembangan Produk Bahan Ajar}

Melalui serangkaian kegiatan penelitian maupun pengembangan dihasilkan produk bahan ajar keterampilan menulis esai dan cerpen yang berbasis project based learning. Keunggulan dari bahan ajar yang dikembangkan ini ada pada struktur dan substansi proyek yang dinamakan project based learning. Pada bab pertama dan kedua serta bagian "Yuk pahami dulu" berisi materi yang digunakan sebagai bekal pengetahuan bagi santri. Literasi menulis dapat diartikan dengan menulis untuk belajar. Hal ini dikarenakan menulis merupakan hal yang dibutuhkan dalam proses belajar. Adanya proses kritis, melakukan perbandingkan, memberi contoh dan menguraikan dalam kalimat yang cocok untuk dipahami pembaca merupakan bentuk proses kreatif dalam menulis (Hasani, Hendrayana, \& Senjaya, 2017).

Bahan ajar ini memberikan kesempatan kepada santri untuk mengasah kemampuan kreatif produktif melalui aktifitas "Proyek Keren Kita". Alur pembelajaran menulis diintegrasikan dengan menggunakan metode project based learning. Proses menulis memiliki beberapa tahapan. Tahapan tersebut yakni pramenulis yang terdiri dari penentuan topic, penentuan tujuan dan bahan, penulisan draf meliputi pengembangan paragraf, kalimat, pemilihan kata dan teknik penulisan dan diakhiri dengan kegiatan pasca menulis yakni merevisi tulisan (Sobari, 2015).

Pada bahan ajar ini tahapan tersebut diintegrasikan dengan project based learning yang meliputi menganalisis masalah, mendesain dan menjadwal langkah, melaksanakan penelitian, menyusun draft produk, menilai dan merevisi produk awal, finalisasi dan publikasi produk. Pemaduan antara penguasaan aspek isi tulisan dan strategi menulis akan membantu mahasiswa mengembangkan keterampilan menulis (Sakaria \& Nojeng, 2018). Pengembangan ini menghasilkan aktivitas "Proyek Keren Kita" yang bersifat kolaboratif sebagaimana disebutkan dalam bahan ajar. Pemaknaan dari desain bagian tersebut akan dijabarkan di bawah ini.

Pertama, tahapan yang diberi nama "Aku Perlu Tahu". Bagian ini berisi tentang pengenalan permasalahan yang akan diangkat dalam proyek. Sesuai dengan tahapan pertama dalam metode project based learning yang juga menyebutkan pentingnya start with the essensial question yang berarti pembelajaran harus diawali dengan pertanyaan yang dapat memberikan penugasan pada siswa dalam bentuk aktivitas. Pada tahapan ini pengembang juga menggunakan bantuan augmented reality dan QR code. Augmented reality yang menggunakan aplikasi UniteAR ini berisi video yang memaparkan tentang permasalahan yang telah dipilih oleh santri sebagai permasalahan yang menarik untuk diamati dan ditulis.

Penggunaan AR dan QR ini sesuai dengan pendapat bellanca yang menyebutkan bahwa penggunaan teknologi secara sengaja ke dalam proyek pembelajaran yang diperkaya selain menjadi pembeda dengan proyek pembelajaran tradisional juga sebagai alat untuk meningkatkan efektivitas belajar siswa (Bellanca, 2012). Pemilihan QR code karena di beberapa smartphone saat ini sudah dilengkapi dengan pemindai QR code. Selain itu, perangkat pemindai juga mudah diunduh di playstore. Pemilihan penggunaan augmented reality dengan UniteAR adalah aplikasi yang mudah diunduh dan langsung dapat digunakan untuk memindai gambar, pada penelitian yang dilakukan oleh Yuliono, terbukti bahwa Augmented Reality (AR) mampu menjadi media pembelajaran yang menarik dan interaktif sehingga dapat meningkatkan motivasi belajar peserta didik (Yuliono, Sarwanto, \& Rintayati, 2018). Selanjutnya, terdapat template think-pair-share yang digunakan untuk mengidentifikasi permasalahan dalam video dan website yang telah dilihat dan dibaca oleh siswa. Template think-pair-share ini cocok digunakan untuk pembelajaran project based learning yang dilakukan secara kolaboratif (Adams \& Hamm 1994; Bender, 2012). Selain itu, template ini juga merupakan strategi cooperative learning yang memberikan kesempatan untuk bekerja secara individu, patner sampai dengan berbagi pada grup yang besar (Schlemmer \& Schlemmer pada Bender, 2012).

Tahapan kedua yakni dengan nama "Rencana Proyek Kita". Pada bagian ini pengembang membuat tabel rencana proyek yang berisi tentang spesifikasi proyek secara detail. Tabel ini diadopsi dari tabel bekerja dengan standar antar disiplin ilmu. Dengan tabel ini guru sedang melatih praktik penelitian di dalam pembelajaran dengan kinerja tinggi. Selain itu, juga sebagai upaya memancing minat siswa dan memotivasi untuk merasa butuh menemukan jawaban daripada dengan disajikan kepada mereka (Feuerstein, Falik, Feuerstein \& Rand, dalam Bellanca, 2012). Tabel ini berfungsi untuk memberikan pengalaman belajar yang bermakna bagi siswa. Dengan memperhatikan hasil apa yang harus diselesaikan, standart apa saja yang harus dipenuhi dan apa gagasan besarnya siswa dengan kolaboratif mendapatkan banyak pengalaman dan pengembangan dalam keterampilan berpikir kritis dan kreatif. Selain itu, disediakan timeline proyek yang berguna untuk merencanakan deadline tiap tugas beserta penanggungjawabnya. Tabel ini disebut juga dengan project management responsibilities schedule (Bender, 2012) tabel ini berfungsi untuk menggabungkan antara rencana pengaturan timeline dengan tugas berkaitan dengan project based learning. Setelah itu, tahap ketiga dengan judul "Mengumpulkan data". Tahapan ini sesuai dengan tahapan ketiga dalam project based learning yakni melaksanakan penelitian. Pada tahap ini pengembang memberikan beberapa pertanyaan yang berguna untuk mengarahkan siswa dalam melakukan penelitian dan proses pengumpulan data. Pertanyaan yang mengarahkan adalah komponen utama dalam project based learning. Pertanyaan ini dapat dikembangkan oleh guru maupun siswa sendiri sebagai bagian dari pembuatan proyek. 
Tahap keempat yakni "Mencipta Kerangka". Bagian ini sesuai dengan langkah keempat project based learning yakni menyusun draf produk. Untuk memudahkan penyusunan draf awal produk maka diberikan tabel maupun kolom untuk membantu siswa dalam mengendapkan idenya. Pengembangan kerangka ini disesuaikan dengan jenis tulisan yang akan dihasilkan. Hal ini disesuaikan dengan unsur-unsur yang membangun tulisan tersebut. Setelah itu disediakan tempat untuk mulai menulis draft tulisan.

Menilai proyek adalah tahap kelima. Langkah kelima dalam project based learning yakni menilai dan merevisi produk awal. Pada aktivitas ini disediakan rubrik yang dapat digunakan menilai produk kelompok lain. Tabel ini diadopsi dari tabel penilaian cerpen yang disusun oleh Dr. Sukirno, M.Pd. dengan melakukan penyempurnaan sesuai dengan kebutuhan. Setelah itu yakni "Mempublikasikan tulisan" Aktivitas ini merupakan tahapan terakhir project based learning. Pada tahap ini pengembang menyajikan salah satu tutorial untuk mempublikasikan baik di website pondok pesantren secara pribadi maupun mengirimkan tulisan ke media massa baik online maupun offline. Mempublikasikan tulisan ini juga sebagai usaha merayakan apa yang telah dibuat oleh siswa dengan susah payah (Sukirno, 2010) pertanyaan memberi penghormatan dan penghargaan kepada siswa yang telah menyelesaikan tugasnya dengan usaha keras, penuh ketekunan dan berhasil dengan sukses. Selain itu, agar memberikan rasa candu bagi siswa untuk mempublikasikan karyanya dan termotivasi untuk terus berkarya.

Tampilan bahan ajar mempunyai peran yang sangat penting, karena menarik atau tidaknya ditentukan oleh tampilan (Wahyuningtyas, 2016). Secara keseluruhan, tema desain tampilan bahan ajar ini adalah dengan warna biru dan dengan font dan icon-icon sub bab yang didesain luwes tidak kaku. Berdasarkan cara pandang ilmu psikologi warna biru muda membantu menenangkan pikiran dan meningkatkan konsentrasi, juga memberikan efek positif pada kemampuan komunikasi dan ekspresi artistik yang mana diperlukan dalam proses menulis. Pemilihan font yang cenderung handwriting dan icon-icon yang berbentuk luwes bertujuan agar pembaca dapat menikmati buku dengan rileks dan tidak bosan.

\section{Kajian Hasil Uji Kelayakan Produk Bahan Ajar}

Melalui uji validitas, ditemukan bahwa bahan ajar dinyatakan sangat layak digunakan dalam pembelajaran. Berdasarkan pengolahan data ahli materi yang telah dipaparkan di paparan hasil, persentase tingkat kevalidan materi bahan ajar adalah $98.75 \%$. Jika dihubungkan dengan tabel kriteria tingkat kelayakan, nilai persentase sebesar $98.75 \%$, sedangkan data ahli media menunjukkan bahwa perhitungan persentase tingkat kevalidan media bahan ajar adalah 99.47\%. Jika dihubungkan dengan tabel kriteria tingkat kelayakan, kedua penilaian tersebut termasuk dalam kriteria (80 - 100\%) yang bermakna bahwa bahan ajar keterampilan menulis untuk santri yang dikembangkan ini dinyatakan sangat valid dan layak dimanfaatkan dalam pembelajaran.

Hasil penilaian pengguna pada uji coba lapangan menunjukkan persentase tingkat kepraktisan bahan ajar adalah $86,29 \%$. Jika dihubungkan dengan tabel kriteria tingkat kepraktisan, nilai persentase sebesar 86,29\% juga termasuk dalam kriteria (80-100\%) yang bermakna bahwa bahan ajar keterampilan menulis untuk santri yang dikembangkan ini dinyatakan sangat praktis untuk digunakan. Hasil dari validasi dan ujicoba tersebut dapat diartikan dengan bahan ajar keterampilan menulis esai dan cerpen berbasis project based learning ini telah memenuhi kriteria kelayakan dalam aspek isi, penyajian, kegrafikan, kebahasaan, kemenarikan dan kemudahan pemahaman. Menurut BSNP (2006), bahan ajar yang berkualitas wajib memenuhi aspek kelayakan, meliputi kelayakan isi, kelayakan penyajian, kelayakan bahasa, dan kelayakan kegrafikaan. Berdasarkan hasil pengolahan data tersebut, bahan ajar menulis esai dan cerita pendek berbasis project based learning ini telah memenuhi kriteria kelayakan. Hal ini mengindikasikan bahwa bahan ajar memenuhi kualitas dan dapat digunakan secara luas.

\section{SIMPULAN}

Penelitian ini menghasilkan produk bahan ajar keterampilan menulis esai dan cerita pendek berbasis project based learning untuk santri. Secara umum, bahan ajar ini terdiri dari empat bab yakni latar belakang menulis bagi santri, jenis-jenis tulisan, belajar menulis esai dan belajar menulis cerita pendek. Metode project based learning diintegrasikan ke dalam bahan ajar secara langsung dalam aktivitas proyek keren kita. Sesuai dengan sintaks project based learning, aktivitas proyek keren kita ini kemudian memiliki enam sub bab (1) aku perlu tahu, (2) rencana proyek kita dan timeline proyek, (3) mengumpulkan data, (4) mencipta kerangka, (5) menilai proyek, dan (6) mempublikasikan esai.

Produk tersebut selanjutnya diujicobakan kepada ahli materi, ahli media dan pengguna/santri. Berdasarkan uji coba tersebut diperoleh persentase sebagai berikut (a) aspek kelayakan isi 93,75\%, (b) aspek kelayakan penyajian 100\%, (c) aspek kegrafikan 99,3\%, (d) aspek kebahasaan 100\%, (e) aspek kemenarikan bahan ajar 85,28\%, dan (f) aspek kemudahan pemahaman bahan ajar $86,82 \%$. Setelah melakukan proses uji coba, produk direvisi berdasarkan saran yang diperoleh dari ahli maupun pengguna. Aspek yang direvisi yakni penggunaan bahasa, kemenarikan, dan kemudahan pemahaman bahan ajar.

Bahan ajar keterampilan menulis esai dan cerita pendek berbasis project based learning ini diharapkan dapat menunjang pembelajaran kepenulisan di pondok pesantren sehingga memudahkan santri untuk mengasah kemampuan kreatif produktif terhadap berbagai genre tulisan. Bagi peneliti lain, pengembangan bahan ajar yang telah dilakukan diharapkan dapat menjadi sumber inspirasi dan pertimbangan dalam mengembangkan bahan ajar yang diintegrasikan pada metode pembelajaran. Bagi pihak pesantren akan lebih baik jika bahan ajar ini dapat digunakan dan didistribusikan kepada para santri agar memberikan manfaat yang lebih luas. 


\section{DAFTAR RUJUKAN}

Aziz, Y. (2011). Pesantren dan Budaya Kepenulisan. Millah, XI(1), 253-273.

Abidin, Y., Mulyati, T., \& Yunansah, H. (2017). Pembelajaran Literasi: Strategi Meningkatkan Kemampuan Literasi Matematika, Sains, Membaca dan Menulis. Jakarta: Bumi Aksara.

Bellanca, J. (2012). Proyek Pembelajaran yang diperkaya: Jalur Praktis Menuju Keterampilan ke Abad ke-21. Jakarta Barat: PT. Indeks.

Bender, W. N. (2012). Project-Based Learning: Differentiating Instruction for the $21^{\text {st }}$ Century. Corwin Press.

Hasani, A., Hendrayana, A., \& Senjaya, A. (2017). Using Project-based Learning in Writing an Educational Article : An Experience Report. Universal Journal of Educational Research, 5(6), 960-964. https://doi.org/10.13189/ujer.2017.050608

Sakaria., \& Nojeng, A. (2018). Bahan Ajar Menulis Opini dan Esai dengan Pembelajaran Berbasis Proyek. RETORIKA: Jurnal Bahasa, Sastra dan Pengajarannya, 11, 68-76. https://doi.org/10.26858/retorika.v11i1.4965

Sharifah, R., \& Faaizah, S. (2015). The Development of Online Project Based Collaborative Learning using ADDIE Model. Procedia - Social and Behavioral Sciences, 195, 1803-1812. https://doi.org/10.1016/j.sbspro.2015.06.392

Sobari, T. (2015). Penerapan Teknik Siklus Belajar Dalam Pembelajaran Menulis Laporan Ilmiah Berbasis Vokasional di SMK. Semantik: Jurnal Ilmiah Program Studi Pendidikan Bahasa dan Sastra Indonesia, 1(1), 17-41.

Sukirno. (2010). Belajar Cepat Menulis Kreatif Berbasis Kuantum: Untuk yang Ingin Cepat Terampil Menulis Kreatif. Yogyakarta: Pustaka Pelajar.

Sutama, I. M. (2013). Pembelajaran Menulis Berbasis Penemuan. Konferensi Nasional Bahasa dan Sastra III, (1), 446-450.

Yarmi, G. (2014). Meningkatkan Kemampuan Menulis Kreatif Siswa melalui Pendekatan Whole Language dengan Teknik Menulis Jurnal. Perspektif Ilmu Pendidikan, 28(1), 8-16.

Yuliono, T., Sarwanto., \& Rintayati, P. (2018). Keefektifan Media Pemelajaran Augmented Reality terhadap Penguasaan Konsep Sistem Pencernaan Manusia. Jurnal Pendidikan Dasar, 9(1), 65-84. 